\title{
Employees' Perspectives on Corporate Social Responsibility: A Focus Group Study in Izmir City
}

\author{
Çalışanların Kurumsal Sosyal Sorumluluğa Bakışları: İzmir \\ İlinde Bir Odak Grup Çalışması
}

Secil Ugur, Izmir University of Economics, Turkey, secil.ugur@izmirekonomi.edu.tr Emel Kursunluoglu Yarimoglu, Yasar University, Turkey, emel.kursunluoglu@ yasar.edu.tr

\begin{abstract}
The aim of this research is to examine how white collar employees working at the Izmir offices of large-sized international companies in Turkey understand and interpret Corporate Social Responsibility (CSR) concept. Focus group interview as one of the techniques of qualitative research method was used in this study. The focus group interview that was conducted with eight businesspeople brought out their opinions into light, and thus more profound data regarding CSR was collected and also localized accounts of personal views and experiences were presented. The primary findings of the research were grouped into seven categories: Selection of the CSR activity; Reason(s) for conducting a CSR activity; CSR and being an ethical business; CSR training; CSR and company image; CSR, a matter of budget; CSR, a matter of spending time or money. On the other hand, "CSR-related words and phrases" and "motivations and concerns behind CSR activities" were also elicited as secondary findings of the research. There were three limitations in the study: the research was conducted only in Izmir city, there was only one focus group, and the participants were all from international companies. To be able to gain a deeper understanding about the issue and then compare the views of different groups of employees on CSR, further research is suggested.
\end{abstract}

Keywords: Corporate Social Responsibility, Focus group, Employees, Turkey.

Öz: Bu çalışmanın amacı; Türkiye'deki büyük ölçekli uluslararası firmaların İzmir şubelerinde çalışan beyaz yakalı çalışanların, Kurumsal Sosyal Sorumluluk (KSS) kavramını nasıl anladıklarını ve yorumladıklarını incelemektir. Bu çalışmada, nitel araştırma yöntemi tekniklerinden biri olan odak grup görüşmesi kullanılmıştır. Sekiz çalışan ile yapılan odak grup görüşmesi sonucunda; bu çalışanların kurumsal sosyal sorumluluk hakkındaki düşünceleri öğrenilmiş, ve böylece KSS ile ilgili daha kapsaml veri toplanılmış ve ayrıca kişisel görüş ve tecrübeler yerel seviyede gösterilmiştir. Araştırmadan elde edilen birincil bulgular yedi gruba ayrılmıştır: KSS faaliyetinin seçimi; KSS faaliyeti yürütülmesi için neden(ler); KSS ve etik bir işletme olmak; KSS eğitimi; KSS ve işletme imajl; bir bütçe meselesi olarak KSS; zaman veya para harcama yönünden KSS. Diğer yandan, "KSS ile ilișkili kelime ve terimler" ve "KSS faaliyetlerinin arkasindaki motivasyon ve endișeler" ikincil bulgular olarak ortaya çıkmıştır. Çalışmada ü̧̧ kısıt bulunmaktadır: araştırma sadece İzmir ilinde yapılmıştır, sadece bir odak grup kullanılmıştır, katılımcıların hepsi uluslararası firmalardan gelmiştir. Bu konu hakkında daha derin bilgi edinebilmek ve farklı çalışan gruplarının KSS hakkındaki düşüncelerini kıyaslayabilmek için, gelecek araştırmalar tavsiye edilmiştir. Anahtar Kelimeler: Kurumsal Sosyal Sorumluluk, Odak Grup, Çalışanlar, Türkiye.

\section{Introduction}

Bauman and Skitka (2012) stated that corporate social responsibility (CSR) has aroused considerable amount of attention among both practitioners and scholars lately. However, CSR activities' effects on employees were not comprehensively analyzed in the literature (Lee et al., 2012; Lee et al., 2013a; Lee et al., 2013b, Bauman and Skitka, 2012). Nevertheless, although employees are the major stakeholders who undeniably have the most critical role in a company's success, not much is known about whether or how CSR influences them. Besides employees are seen as a major stakeholder of a company, they are also seen as important assets of companies in internal marketing concept (Grönroos, 1981; Sasser and Arbeit, 1976; George, 1990). Because of the importance of employees, their perspectives regarding CSR activities were analyzed in this study.

The aim of this study is to bring out the perspectives of Turkish white collar workers working in Izmir offices of international, large-sized companies about CSR into light by analyzing their personal thoughts, their reflections on their own experiences and attitudes through a focus group study, and 
thus responding to calls for more in-depth data and localized accounts of personal views and experiences. The first section of the study consists of a literature review regarding CSR and employees, the second section explains the aim of the research, and then research methodology, findings, and discussion sections take part in sequence in the study.

\section{Literature Review}

Bowen (1953), who was called as the "Father of CSR" by Carroll (1999), claimed that social responsibility would continue to guide businesses in the future. Lee et al. (2013a) sided with Bowen when they once again reminded that CSR has recently gained growing attention. Hence, this situation urges us to better grasp the link between common CSR strategies and a range of aspects of a company. To clarify the issue, although there are several studies in the CSR literature analyzing how those strategies influence the opinions of a firm's external customers about the business, one cannot say the same is true for internal customers; that is, the employees.

There are numerous definitions of CSR in the extant literature, yet there is still no one common definition (Carroll, 1991; McWilliams and Siegel, 2001; Idowu and Papasolomou, 2007; Idowu 2009). Davis (1960) argued that social responsibility was not done just for profit; it went beyond economic and technical interest. McGuire (1963) argued that social responsibility included economic and legal obligations and also responsibilities to society. Another point of discussion is whether CSR should be an obligation for companies or a voluntary activity. Manne and Wallich (1972) emphasized that CSR should be voluntary activities of companies (Carroll, 1979).

Carroll (1979) categorized the definitions of social responsibility into four types as economic, legal, ethical, and philanthropic social responsibility. Philanthropic social responsibility was defined as being a good corporate citizen and improving the quality of community's life, ethical responsibilities included being ethical, legal responsibilities were related to obeying the law, and economic responsibilities contained being profitable which is already the main aim of organizations. After reviewing general CSR definitions, CSR literature were reviewed in terms of its effects on employees.

Dhanesh (2014) performed an empirical research with 244 employees in India and revealed that there are positive relationships among four dimensions of CSR and employee relationships, and those are trust, commitment, and satisfaction. Then, it was proposed that CSR is a relationship management strategy in the context of employee relations.

Lee et al. (2013a) investigated CSR's effects on employees' organizational trust, job satisfaction, and customer orientation. They conducted an empirical research with casino employees in South Korea. They developed the construct based on the study developed by Carroll in 1979 (Carroll, 1979). According to the findings, legal CSR was significant in explaining organizational trust whereas economic and philanthropic CSR were not related to trust. Also they found out that organizational trust was significant in predicting job satisfaction, and job satisfaction significantly affected customer orientation.

Another research investigated the effects of all four types of CSR on both organizational trust and job satisfaction (Lee et al., 2012). It showed that economic and philanthropic CSR statistically affected organizational trust, and only ethical CSR had positive effects on job satisfaction.

CSR activities affect employee attachment and corporate performance positively. Employee attachment toward the organization increases corporate performance (Lee et al., 2013b). Another research showed that CSR activities positively affected sales employees' perceptions on organization and their behavioral intentions (Vlachos et al.2010; Lee et al., 2012).

Chaudhary (2009) identified the roles of CSR such as boost in brand image and reputation, increased sales and customer loyalty, reduction in operating costs, higher productivity and quality, attracting and retaining employees, and reduced regulatory.

CSR activities also affect competitive advantage. Turban and Greening (1997) analyzed the effects of CSR activities on the performance of employees. They found out that corporate social performance (CSP) influenced the ratings of reputation and attractiveness, and advised that firms should attract high-quality workforce for corporate success to gain competitive advantage. 
According to D'Amato et al. (2009), businesses need to manage their relationships with the wider society. They suggested that CSR should be the main principle of top management and entrepreneurs since they are responsible for their corporations' impacts on society and the natural environment beyond legal compliance and the liability of individuals.

A cross-cultural research based on data from 1,084 employees from 17 countries showed that CSR affected employees' affective commitment (Mueller et al., 2012). Dawkins et al. (2014) analyzed the influences of CSR activities on employees' job choices in three countries: America, China, and Lebanon. They found out that organizations' CSR activities positively affect employees' job choices. They emphasized that American respondents' attitudes toward CSR were more effective on job choice than Chinese and Lebanese respondents. Brammer et al. (2014) showed that CSR affects employees' attitudes and behaviors. Besides this, employee creativity was affected by CSR activities, too.

Although there have been some studies regarding employees and CSR, how Turkish employees working at various industries interpret CSR has remained an underexplored area. CSR concept has been studied from different dimensions in a variety of cities in Turkey. Those studies include the types of CSR activities conducted at Turkish businesses (Ilic, 2010), their influences on brand image (Ozdemir, 2009), its influence on organizational commitment (Turker, 2009), developing a valid and reliable scale for measuring CSR activities (Turker, 2009), the history of the evolution of CSR literature in Turkey (Yamak, 2007), the use of CSR activities as a method of struggling against poverty in Turkey (Orcan, 2007) and its effects on human resources management (Akgeyik, 2010).

\section{Research Question}

Recently, both practitioners and scholars focused on the effects and benefits of CSR activities on companies and customers. However, there have been few studies regarding employees' perspectives on CSR in the literature (Lee et al., 2012; Lee et al., 2013a; Lee et al., 2013b, Bauman and Skitka, 2012). Lee et al. (2013a: 413) explained this situation in the casino industry as: "Although the CSR literature has paid substantial attention to the relationship between CSR strategy and external customers, less attention has been paid to internal customers (i.e., employees)." Rupp et al. (2013: 917) expressed that "Research on the psychology of CSR, and more specifically, employees' perceptions of and reactions to CSR, is only just beginning to amass."

CSR activities' effects on employees and the opinions of employees regarding CSR activities conducted by their firms were not analyzed comprehensively in the literature (Lee et al., 2012; Lee et al., 2013a; Lee et al., 2013b, Bauman and Skitka, 2012). Therefore, this study focused on revealing employees' ideas regarding CSR activities of firms and various employees working at large-sized international companies were selected as a scope of the research.

Analyzing employees' opinions and insights regarding the CSR activities may help companies to develop and enhance their businesses, since the employees are one of the important assets of a company and they can affect company's success directly. As it is also seen in the literature review part of the study, CSR activities can affect employees' trust (Dhanesh, 2014; Lee et al., 2013a; Lee et al., 2012), commitment (Mueller et al., 2012; Dhanesh, 2014), job satisfaction (Lee et al., 2012; Lee et al., 2013a; Dhanesh, 2014), creativity (Brammer et al., 2014), corporate performance (Lee et al., 2013b), job choice (Dawkins et al., 2014), customer orientation (Lee et al., 2013a), attitudes and behaviors (Brammer et al., 2014), attachment (Lee et al., 2013b), and performance (Turban and Greening, 1997).

Employees' reactions to CSR activities are significant feedback for the companies in terms of the success and sustainability of the activity. In the light of the aforementioned reasons, the main research question of this research is as follows:

RQ: How do white collar employees working at large-sized international companies understand and interpret the CSR activities conducted by companies? 


\section{Research Methodology}

This research was designed based on an exploratory and qualitative method. Because of the majority of the studies done in this field adopted quantitative research methods, an exploratory qualitative research was implemented in this study to get deeper insight about the issue. Qualitative research, which is unstructured and based on smaller samples, provides deeper insights and understanding of the problem setting (Malhotra, 2014). Therefore, in this study qualitative research method was used in order to understand the employees' perspectives on CSR in detail.

\subsection{Sampling Technique}

In this study, homogeneous sampling, which is one of the techniques of purposive sampling, was used. This technique involves open-ended discussion of specific matters in groups of five to eight people who come from similar backgrounds and share similar experiences (Patton, 1990:173). Considering that, the sampling criteria were that each participant be Turkish, employed as a whitecollar employee for an international, large-sized firm operating in Izmir city, be aged between 25 and 45 years old. Thus, the sampling criteria considered in this study presented a particular set of circumstances in which we could embed the findings of the study. On the other hand, for the sake of eliciting different perspectives, we selected participants working in different industries and at different positions.

When forming a focus group, having 8-12 participants is generally an accepted number (Krueger, 1994; Stewart and Shamdasani, 1990). Considering that, eighteen businesspeople working at largesized international companies were contacted by phone to invite them to the focus group study. However, only eight businesspeople accepted the invitation because of their busy schedules. The number of participants is enough for conducting one focus group study.

\subsection{Data Collection Method}

In this study, focus group study technique, which is one of the techniques of qualitative research, was adopted. The primary reason why focus group interview was selected as a data collection method is that focus group studies, by their nature, allow the participants to interact with each other and encourage people with different mindsets to produce insights about the dynamics of the subject contrary to the relatively static nature of data collection through questionnaires (Morgan, 1988). Secondly, when compared to the other methods of data collection, focus groups inspire a higher degree of spontaneity when stating opinions (Butler, 1996).

Because focus group interaction exposes more profound information, opinions, and insights than individual interviews and one participant's comment may initiate unexpected reactions and comments from the other participants (Malhotra, 2014), focus group study technique was selected as a data collection method. Data were collected on June, 2014 by bringing the eight participants together in a room. The informants were seated in a semi-circle so that they could see each other's face. After they had been given a special welcome, the moderator explained the aim of the study to the participants clearly. They were assured that their identities would be kept confidential and they would be given pseudonyms. Also, they were asked for permission to record their voices. Then, each participant was asked to introduce himself/herself to the group.

The moderator continued with warm-up questions, and later followed the questions in the Focus Group Protocol presented in Appendix 1. This protocol was prepared by the researchers beforehand. The questions in the protocol were generated by the researchers based on both literature (Q6-Q10) and the research question of the study.

The discussion started with basic terms about CSR and commonly performed CSR activities. It continued with more complex and insight-producing questions where the participants were encouraged to openly discuss what they thought in the group. They were often asked probe questions to motivate them to speak more and clarify their points. The discussion lasted for two and a half hours. 


\subsection{Data Analysis}

First, the two and half hours recording was transcribed verbatim, which resulted in a twenty-page text of rich data. The discourse analysis followed three steps: open coding, axial coding and selective coding, respectively.

In the open coding stage, the transcripts were read several times in their entirety in order to get more familiar with the texts. Then, the most repeated and stressed points were noted in the right column next to the text, yet no interpretation was made at this stage. Thus, the researchers gained a sense of the whole interview before breaking it into specific parts.

In the second stage, axial coding, the transcripts were read more carefully this time. Each respondent's answer to a specific question was compared with the answers of other respondents so as to find overlapping ideas as well as differing opinions. Then, the main similarities and differences that emerged about CSR were noted in the margin. Thus, core themes were disaggregated.

In the final stage, selective coding, the best quotes reflecting the participants' ideas and their personal experiences regarding the main categories were spotted, translated into English and supported with literature whenever possible. Furthermore, the findings referred to the related focus group question in the protocol whenever it was possible to do so.

To assure the reliability of the research, two researchers analyzed the whole data separately and then interpreted the data. When the two separate interpretations were compared, they were synchronized. To assure the validity of the research, member checking technique (Cho and Trent, 2006: 322) was used. The researchers' interpretations of the findings and the whole report were separately e-mailed to the participants of the study to be assessed. They were asked to read the findings and to inform the researchers whether they agreed that those findings really represented their ideas or not. All the participants confirmed that the results exactly represented the discussions they had.

\section{Findings}

The eight businesspeople, three females and five males, participated in the focus group study. The profile of the participants is displayed in Appendix 2. This study has revealed some interesting findings in relation to CSR, admittedly from a small group. Although it was not possible to extrapolate these results to a general population of Turkish business people, the study has indicated recent trends in overall opinions of the Turkish business professionals on CSR.

The findings of the study were separated into two parts such as primary findings and secondary findings of the study. Besides this, the primary findings of the study were divided into seven subfindings:

Finding 1: Selection of the CSR activity

Finding 2: Reason(s) for conducting a CSR activity

Finding 3: CSR and being an ethical business

Finding 4: CSR training

Finding 5: CSR and company image

Finding 6: CSR, a matter of budget

Finding 7: CSR, a matter of spending time or money

As regards Finding 1: Selection of the CSR activity (relates to Q5 in the focus group protocol), whether businesses should engage in CSR activities that are directly related to their core businesses and industries or not, except for one participant, the group members agreed that companies do not necessarily have to conduct CSR operations directly related to their businesses. One participant gave an example from her business in the food industry and emphasized that it was a meaningful CSR activity.

Nil: “Mc Donald's Children's Fund, one of our stakeholders, for example, was awarded a $\$ 10,000$ grant in 2012 for building the Department of Children's Developmental and Behavioral Pediatrics at Sisli Etfal Hospital in Istanbul, Turkey."

Concerning Finding 2: Reason(s) for conducting a CSR activity (relates to Q6 in the focus group protocol), the primary purpose of companies for performing CSR activities, all the group members 
expressed that they are, in fact, done for commercial purposes, to increase sales and so profits. Two answers are shown below:

Kaan: "CSR activities are of common practice, especially among global companies. Do you know why? Because when a global company enters a new country, so a new market, CSR practices are the most influential way of conquering the hearts of people there. That is the best way of telling them that they care about that society and in return, increase your market share in that industry."

Esra: "It's all about making profits. I don't believe that businesses really care about their social responsibilities or improving the welfare of public."

Concerning Finding 3: CSR and being an ethical business (relates to Q7 in the focus group protocol), they were asked to explain if they could think of a relationship between CSR and ethics. All the participants stated that as long as the businesses conduct CSR activities for profit purposes, the practice is not ethical.

Hasan: "I believe that when businesses use their CSR activities as a marketing tool, the practice becomes unethical."

Semih: "As long as it is done for profit-making purposes, it cannot be an ethical deed."

Eser: "The companies conducting CSR activities already have large market shares. They have many customers and are already making profits. So, that they are engaged in a CSR activity should not give them an extra status. They would look, I guess, unethical if they were not doing one."

About Finding 4: CSR training (relates to Q8 in the focus group protocol), the group members were asked about how they felt both about employees and society's being trained on what CSR is, its benefits, and most appropriate CSR practices. Some answers are as follows:

Semih: "I haven't received any training about CSR. The company just encourages us to participate in such projects on a voluntary basis."

Ahmet: "I don't think that companies have to do that. At some companies, they have CSR Departments that take care of that. They deal with those campaigns in a more planned, more professional way."

None of the participants thought that CSR education is necessary. However, they all underlined the necessity of having a "CSR Department" (relates to Q8 in the focus group protocol) at firms to be able to run such operations professionally. Furthermore, half of the group members stated that they already have a specific department in their firms taking care of nothing else but CSR activities.

As regards Finding 5: CSR and company image (relates to Q9 in the focus group protocol); that is, the impression that CSR-performing businesses create in the media, they think that their competitors would find such businesses threatening as they have a more positive impression on public. They agreed that it would create a competitive advantage for those businesses over their competitors. One dialogue between two participants regarding this question is shown below:

Ahmet: "I would not call that success, but they certainly create a better bond with the public....it means that company has adopted that specific community and shows that they are ready to serve their customers in a different way."

Nil: "Yes, but then how would their competitors take that?"

Ahmet: "Well, they would feel threatened, of course! Your competitor is getting closer with society while you make no progress. That would definitely make a difference!"

Nil: "Then they would compare their company with the others and feel the urge to do something about corporate social responsibility."

Regarding Finding 6: CSR, a matter of budget (relates to Q10 in the focus group protocol), all of the participants agreed that performing CSR activities requires a certain budget and that must definitely be considered before initiating a CSR activity. Three participants suggested that as long as they received tax incentives from the government, they would conduct a CSR activity. Some answers are shown below:

Semih: "Businesses had better cooperate with non-governmental organizations. And if they engage in a CSR activity, especially to improve educational conditions at a certain place or contribute to environmental preservation, then it's much easier to receive financial incentives from the Turkish Government."

Ahmet: "The primary purpose of a business is to make a profit, not loss. In Turkey, most business people unfortunately think that the more money a business spends on a CSR campaign, the more 
effectively they will be advertised. Yet, what really matters is not the amount of money spent, but how sustainable that CSR activity is, I believe. You should not exceed the budget with such campaigns, but rather go for sustainable projects."

Similarly, Q11 in the focus group protocol, the question about the continuance of CSR operations at times of economic crisis, led to the consensus that at such times, businesses should either allocate less funds for CSR activities or end them completely. This finding is very well reflected in one participant's explanation:

Ahmet: "I believe that CSR activities must be terminated at times of economic crisis, because the primary purpose of a company is to make a profit. If the company is not making profits due to recession, or making less profits, then there is no point in continuing a CSR activity. Think about this: If I would have to lay some of my employees off because I am not making enough profits but still continuing the CSR campaign, what's the use of it?"

Selen: "If that company has been badly affected by the recession, then they should consider shrinking their budget for CSR activities."

Eser: "Large businesses should first see to what extent they have been affected by recession. If it is not a big loss, then they should continue the project, yet allocate less budget."

With regard to Finding 7: CSR, a matter of spending time or money (relates to Q12 in the focus group protocol), most group members came up with different answers.

Hasan: "People always want to see the solid outcome of contribution. Therefore, I personally believe that spending money on a project is more meaningful than spending personal time. When you look around and see old people's homes, hospitals, children's shelters, you immediately think of the money spent."

Eser: "I think they are each valuable...spending your personal time to help people should mean a lot to them, and the same goes for donating money to improve their lives..."

Nil: "Although I agree with Eser, I must admit that spending time on a project is much more ethical. I mean, voluntarily spending your time to help them is more precious than spending money for a project. That's more humanistic."

Selen: "Each has its own place, of course. But with a commercial motivation, I believe that spending your time looks less rewarding....people care more about how much money you have spent, of course..."

After analyzing seven primary findings of the study, some secondary findings are also acquired. The secondary findings of the study reflect the participants' impressions about various companies' CSR activities, including the firms they are currently working for. "CSR-related words and phrases" and "motivations and concerns behind CSR activities" are the secondary findings of the research explained below.

When the eight participants were asked to come up with words and phrases about CSR in Q2 in the focus group protocol, they produced a long list of CSR-related words and phrases. The most frequently repeated phrases were: company reputation, prestige, brand awareness, competitive advantage, sustainability, customer satisfaction, profit making, marketing, legal responsibility, tax incentive, socioeconomic support, environmental sensitivity, educational support, raising awareness about a specific disease, secret donation, and events sponsorship.

The reallife examples they gave about the types of CSR practices, especially in Q3 and Q4, have led the researchers to offer three main categories to define the motivations and concerns behind CSR activities:

Economic motivations and concerns: 1) profit making; 2) an effort to increase brand recognition and customer satisfaction; 3 ) an endeavor to gain a competitive advantage.

Social motivations and concerns: 1) a philanthropic approach; 2) a support for cultural activities such as concerts, sports events, and restoration of historic sites; 3 ) an effort to raise awareness about certain diseases; 4) an effort to improve the lives of physically handicapped people; 5) an attempt to raise awareness about the importance of education.

Environmental motivations and concerns: 1) recycling and waste management; 2) forestation. 


\section{Discussion}

In the first finding of the study, regarding what projects to engage in, the informants say that companies do not necessarily have to develop projects that fit their core businesses. According to their ideas, for example, a hospital does not have to implement a CSR activity related to health as that is its core business; it may also organize CSR activities related to education, art and culture. They should rather be encouraged for diversity and creativity when producing CSR activities.

In the second finding of this study, it was argued that the growing interest in CSR does not necessarily mean that businesses always pursue such activities to improve the well-being of societies without an expectation. Economic concerns come out as a significant factor here. The major expectancy is to increase customer satisfaction and brand recognition, which will pave the way for increased profits and a larger market share. Although, as shown in secondary findings, all participants gave reallife examples of CSR activities conducted to protect the environment, help the needy in societies, create funds for fatal diseases, attract attention to cultural activities and so on, their common belief is that the underlying motivation is eventually to increase profits. On the contrary of this finding, in reallife CSR activities should be conducted for social and environmental concerns much more than economic concerns.

The third finding of the study showed that if CSR activities are performed with an economic concern, then those businesses are not being ethical. All the participants stated that as long as the businesses conduct CSR activities for profit purposes, the practices are not ethical. In the light of this finding, it can be advised that companies had better consider improving the welfare of the society in the first place. If they do not, society believes that companies organize CSR activities for their own benefits and profits. Then, it is considered unethical.

In the fourth finding, the participants emphasized the necessity of having a "CSR Department" at firms to be able to run such operations professionally. Some of the participants said that they already have a specific CSR department in their firms, although in Turkey there is no specific policy forcing enterprises to have CSR-related positions (Gocenoglu and Onan, 2008).

The fifth finding demonstrates that being involved in a CSR activity strengthens a company's image, prestige, and gives them a competitive advantage over their competitors, which makes it look more successful than their rivals. This finding shows the rising importance of CSR activities.

In the sixth finding, all of the participants agreed that performing CSR activities requires a certain budget and that must definitely be considered before initiating a CSR activity. Three participants suggested that as long as they received tax incentives from the government, they would conduct a CSR activity. Gocenoglu and Onan (2008) also report that the Article 193 of the Income Tax Law explain the tax incentives for CSR activities. Article 89 of the same Law manifests that businesses will benefit from tax incentive for their financial and other kinds of contributions in the field of education. Even though some companies may know that, the Turkish Government should promote campaigns to increase more awareness about the tax incentives they offer. They must be encouraged to support special educational campaigns executed by UNICEF and the Ministry of Education such as "100\% Support for Education" and the "Girls' Education Campaign in Turkey".

The group members also explained their concerns about the sustainability of a CSR activities at times of recession. They have all agreed that businesses should either allocate less funds for CSR activities or end them completely during economic crisis. If a business involved in a project can withstand the economic turbulence, then it should continue the project, yet limit the budget allocated for that project.

The last finding showed that CSR activities should be conducted by both spending money and time in order to contribute to the society. The participants have varying opinions about which one is more rewarding for businesses, voluntarily spending their time to help the society and their wellbeing or simply spending money on projects but not personally engaging in the project. Some favour the former while some others approve of the latter. Regarding the latter, the discussions have also revealed that no matter how small-scale or short-term a project is, it definitely requires a budget.

Finally, it can be said that CSR activities were interpreted as essential and beneficial activities by the employees who work at international companies and participated in the research. The number of 
CSR activities should be increased since CSR activities affect employees' attitudes and behaviors positively and increase their commitment and satisfaction to their companies.

\section{Limitations and Suggestions for Further Research}

There were three limitations in the study. First, this study was conducted only in Izmir city due to financial restrictions. It is recommended to carry out a similar study in other industrial cities in Turkey. Second, one focus group study was used in this inquiry. Scholars are encouraged to do further research on the same issue using other research techniques such as in-depth interviewing or survey. Yet, this time it is suggested that they should employ triangulation method to reveal even more comprehensive data. Third, the study was conducted only with Turkish employees working at large-sized international companies. Hence, it is recommended that another qualitative study should be carried out with Turkish employees working at national companies and also small and medium sized enterprises this time. Thus, the differences as well as similarities in Turkish employees' perspectives about CSR can be revealed. 


\section{REFERENCES}

Akgeyik, T. (2010). İnsan Kaynakları Yönetimi Boyutuyla Kurumsal Sosyal Sorumluluk: (Bir Alan Araştırmas1). Sosyal Siyaset Konferansları Dergisi, 52, 65-106.

Bauman, C. W., \& Skitka, L. J. (2012). Corporate social responsibility as a source of employee satisfaction. Research in Organizational Behavior, 32, 63-86.

Bowen, H. R. (1953). Social responsibilities of the businessman. New York: Harper \& Row.

Brammer, S., He, H., \& Mellahi, K. (2014). Corporate Social Responsibility, Employee Organizational Identification, and Creative Effort The Moderating Impact of Corporate Ability. Group \& Organization Management, 1-30.

Butler, S. (1996). Child protection or professional self-preservation by the baby nurses? Public health nurses and child protection in Ireland. Social Science and Medicine, 43(3), 303-314.

Carroll, A. B. (1979). A three-dimensional conceptual model of corporate performance. Academy of management review, 4(4), 497-505.

Carroll, A. B. (1991). The pyramid of corporate social responsibility: toward the moral management of organizational stakeholders. Business horizons, 34(4), 39-48.

Carroll, A. B. (1999). Corporate social responsibility evolution of a definitional construct. Business \& society, 38(3), 268-295.

Chaudhary. N. K. (2009). Facilitators \& Bottlenecks of Corporate Social Responsibility. The Indian Journal of Industrial Relations, 44(3), 386-395.

Cho, J. \& Trent, A. (2006). Validity in qualitative research revisited. Qualitative research, 6(3), 319340.

D’Amato, A., Henderson, S., \& Florence, S. (2009). Corporate Social Responsibility and Sustainable Business: A guide to Leadership Tasks and Functions. North Carolina: CCL Press.

Davis, K. (1960). Can business afford to ignore social responsibilities?. California Management Review, 2(3), 70-76.

Dawkins, C. E., Jamali, D., Karam, C., Lin, L., \& Zhao, J. (2014). Corporate Social Responsibility and Job Choice Intentions A Cross-Cultural Analysis.Business \& Society, 1-35.

Dhanesh, G. S. (2014). CSR as Organization-Employee Relationship Management Strategy A Case Study of Socially Responsible Information Technology Companies in India. Management Communication Quarterly, 28(1), 130-149.

George, W. R. (1990). Internal Marketing and Organisational Behaviour: A Partnership in Developing Customer-Conscious Employees at Every Level. Journal of Business Research, 20(1), 63-70.

Gocenoglu, C. \& Onan, I. (2008). Türkiye'de Kurumsal Sosyal Sorumluluk. Avrupa Komisyonu.

Grönroos, C. (1981). Internal Marketing-An Integral Part of Marketing Theory, Ed. J. H. Donnelly and W. R. George, Marketing of Services, Chicago: American Marketing Association, 236-238.

Idowu, S. O. (2009). The United Kingdom of Great Britain and Northern Ireland (pp. 11-35). In Global Practices of Corporate Social Responsibility. Eds: Idowu, S. O. \& Filho, W. L., Verlag Berlin Heidelberg: Springer.

Idowu, S. O. \& Papasolomou, I. (2007). Are the corporate social responsibility matters based on good intentions or false pretences? An empirical study of the motivations behind the issuing of CSR reports by UK companies. Corporate Governance, 7(2), 136-147.

Ilic, D. K. (2010). İșletmelerin Kurumsal Sosyal Sorumluluk Düzeylerinin Belirlenmesine Yönelik Bir Literatür Taramas1. Ege Academic Review, 10(1), 303-318.

Krueger, R. A. \& Casey, M. A. (1994). Focus Groups: A Practical Guide for Applied Research. California: Sage Publications.

Lee, Y. K., Lee, K. H., \& Li, D. X. (2012). The impact of CSR on relationship quality and relationship outcomes: A perspective of service employees. International Journal of Hospitality Management, 31(3), 745-756.

Lee, C. K., Song, H. J., Lee, H. M., Lee, S., \& Bernhard, B. J. (2013a). The impact of CSR on casino employees' organizational trust, job satisfaction, and customer orientation: An empirical examination of responsible gambling strategies. International Journal of Hospitality Management, 33, 406-415. 
Lee, E. M., Park, S. Y., \& Lee, H. J. (2013b). Employee perception of CSR activities: Its antecedents and consequences. Journal of business research, 66(10), 1716-1724.

Malhotra, N. K. (2014). Essentials of Marketing Research: A Hands-On Orientation. Pearson Education.

Manne, H. \& Wallich, H. C. (1972). The modern corporation and social responsibility. Washington D.C.: American Enterprise Institute for Public Policy Research.

McGuire, J. W. (1963). Business and society. New York: McGraw-Hill.

McWilliams, A., \& Siegel, D. (2001). Corporate social responsibility: A theory of the firm perspective. Academy of management review, 26(1), 117-127.

Morgan, D. L. (1988). Focus Groups as Qualitative Research. California: Sage Publications.

Mueller, K., Hattrup, K., Spiess, S. O., \& Lin-Hi, N. (2012). The effects of corporate social responsibility on employees' affective commitment: A cross-cultural investigation. Journal of Applied Psychology, 97(6), 1186.

Orcan, M. (2007). Yoksullukla Mücadelede Kurumsal Sosyal sorumluluk (KSS) Kampanyaları. Afyon Kocatepe Universitesi I.I.B.F. Dergisi, 9(2), 27-37.

Ozdemir, H. (2009). Kurumsal Sosyal Sorumluluğun Marka İmajına Etkisi. İstanbul Ticaret Üniversitesi Sosyal Bilimler Dergisi, 8(15), 57-72.

Patton, M. Q. (1990). Qualitative Evaluation and research methods ( $2^{\text {nd }}$ ed.). Thousand Oaks, CA, US: Sage Publications Inc.

Rupp, D. E., Shao, R., Thornton, M. A., \& Skarlicki, D. P. (2013). Applicants' and Employees' Reactions to Corporate Social Responsibility: The Moderating Effects of First-Party Justice Perceptions and Moral Identity. Personnel Psychology, 66(4), 895-933.

Sasser, W. E. \& S. P. Arbeit. (1976). Selling Jobs in the Service Sector. Business Horizons, 19(3), 6165.

Stewart, D. W. \& Shamdasani, P. N. (1990). Focus Groups: Theory and Practice. California: Sage Pub.

Turban, D. B. \& Greening, D. W. (1997). Corporate social performance and organizational attractiveness to prospective employees. Academy of Management Journal, 40(3), 658-672.

Turker, D. (2009). Measuring corporate social responsibility: A scale development study. Journal of Business Ethics, 85(4), 411-427.

Vlachos, P., Theotokis, A. \& Panagopoulos, N. (2010). Sales-force reactions to corporate social responsibility: attributions, outcomes and the mediating role of trust. Industrial Marketing Management. 39 (7), 1207-1218.

Yamak, S. (2007). Kurumsal Sosyal Sorumluluk Kavramının Gelişimi. İstanbul: Beta Basım. 


\section{Appendix 1. Focus Group Protocol}

Q1. Could you briefly introduce yourselves and the businesses you are currently working for?

Q2. Now, think about the phrase "Corporate Social Responsibility" and write down the words and phrases CSR associates to you.

Q3. Could you make a quick list of CSR activities that you can think of?

Q4. Here is a list of commonly conducted CSR activities. Go over the list carefully, and tick the ones that your company has performed/has been performing. If your company is performing a CSR activity that is not on this list, please explain that.

Q5. Does a business necessarily have to perform a CSR activity in the same industry they specialize in?

Q6. Why do you think businesses carry out CSR activities?

Q7. Do you think that there is a relationship between the concept of "Corporate Social Responsibility" and the word "ethics"?

Q8. Is there a CSR Department at the company you are currently working for? If not, do you think that there should be one? Why/Why not?

Q9. Do you think that consumers, media, government, and competitors see a company engaged in CSR activities as more successful than the others?

Q10. It is known that CSR activities have a cost to businesses. Is it worth the cost? them?

Q11. Should businesses terminate their CSR activities at times of economic crisis or continue

Q12. Which one do you think society values more, a business spending their money or time to improve the well-being of society? 
Appendix 2. Demographic Profiles of the Focus Group Participants

\begin{tabular}{|c|c|c|c|c|c|c|c|}
\hline No. & Pseudonym & Gender & Age & Education & Industry & Profession & $\begin{array}{l}\text { Position \& } \\
\text { Department }\end{array}$ \\
\hline 1 & Kaan & Male & 35 & $\begin{array}{l}\text { University } \\
\text { Graduate }\end{array}$ & Banking & $\begin{array}{l}\text { Public Relations } \\
\text { Specialist }\end{array}$ & $\begin{array}{l}\text { PR specialist at the } \\
\text { Department of } \\
\text { Corporate } \\
\text { Communication and } \\
\text { Marketing } \\
\end{array}$ \\
\hline 2 & Semih & Male & 27 & $\begin{array}{l}\text { University } \\
\text { Graduate }\end{array}$ & $\begin{array}{l}\text { Container } \\
\text { Shipping }\end{array}$ & \begin{tabular}{|l} 
Logistics \\
Specialist
\end{tabular} & $\begin{array}{l}\text { Process analyst at } \\
\text { the Department of } \\
\text { Process Analysis and } \\
\text { Operational } \\
\text { Excellence } \\
\end{array}$ \\
\hline 3 & Selen & Female & 33 & $\begin{array}{l}\text { University } \\
\text { Graduate }\end{array}$ & $\begin{array}{l}\text { Fashion and } \\
\text { Garment }\end{array}$ & $\begin{array}{l}\text { Leather } \\
\text { Engineer }\end{array}$ & $\begin{array}{l}\text { Turkey leather } \\
\text { specialist of a Men } \\
\text { Leatherwear } \\
\text { Company }\end{array}$ \\
\hline 4 & Nil & Female & 35 & $\begin{array}{l}\text { Master } \\
\text { Graduate }\end{array}$ & Food Industry & Food Engineer & \begin{tabular}{|l} 
Key Account \\
Manager at the \\
Department of Sales
\end{tabular} \\
\hline 5 & Ahmet & Male & 32 & $\begin{array}{l}\text { University } \\
\text { Graduate }\end{array}$ & Tobacco Industry & $\begin{array}{l}\text { Industrial } \\
\text { Engineer }\end{array}$ & \begin{tabular}{|l} 
Manager at the \\
Department of \\
Quality Assurance
\end{tabular} \\
\hline 6 & Esra & Female & 32 & $\begin{array}{l}\text { University } \\
\text { Graduate }\end{array}$ & $\begin{array}{l}\text { Industrial Pumps } \\
\text { Manufacturing }\end{array}$ & \begin{tabular}{|l} 
Finance \\
Specialist
\end{tabular} & $\begin{array}{l}\text { Finance Supervisor } \\
\text { at the Department of } \\
\text { Finance }\end{array}$ \\
\hline 7 & Hasan & Male & 26 & $\begin{array}{l}\text { Master } \\
\text { Graduate }\end{array}$ & \begin{tabular}{|l} 
Fast Moving \\
Consumer Goods
\end{tabular} & $\begin{array}{l}\text { Industrial } \\
\text { Engineer }\end{array}$ & $\begin{array}{l}\text { Project Manager at } \\
\text { the Department of } \\
\text { Production Planning } \\
\text { and Supply Chain }\end{array}$ \\
\hline 8 & Eser & Male & 41 & $\begin{array}{l}\text { University } \\
\text { Graduate }\end{array}$ & $\begin{array}{l}\text { Machinery } \\
\text { Manufacturing }\end{array}$ & $\begin{array}{l}\text { Machinery } \\
\text { Engineer }\end{array}$ & General Manager \\
\hline
\end{tabular}

